\title{
Contribution of the requirements engineering to the evaluation of water resources systems efficiency
}

\author{
Bouchrit Rouissat $^{1}$ (i) $\cdot$ Abdelmalek Bekkouche $^{1} \cdot$ Nadia Smail $^{1}$
}

Received: 2 February 2017 / Accepted: 6 January 2021 / Published online: 25 January 2021

(c) The Author(s) 2021

\begin{abstract}
In the water resources sector, the need to adopt a new way of thinking based on a systemic approach and analysis is justified by several situations: very complex constraints that accompany the development of the sector, functional interactions between various planned developments and the multitude of actors and stakeholders involved. System engineering is a general methodological approach that encompasses all the appropriate activities to design, evolve and verify a system providing an economical and efficient solution to the needs of customers while satisfying the whole of stakeholders. Based on these concepts of size, the purpose of this paper is to apply the principles of systems engineering for the exploration and evaluation of Boughrara water resources system performance. This system located in the north-west of Algeria involves subsystems in constant interaction, namely mobilization, treatment, purification and transfer of water. Its performance takes into account a number of parameters: compliance with customer satisfaction objectives, system constraints, stakeholder role and responsibility for achieving system-wide objectives, and not relationship with sectors of activity.
\end{abstract}

Keywords Boughrara $\cdot$ Water resources $\cdot$ System $\cdot$ System engineering $\cdot$ Performance

\section{Introduction}

The systemic approach has been widely used in many areas: the industry in general, the space, aeronautics, medicine, nuclear, etc., where all the systems have been designed using a systemic approach. In the water resources sector, this approach has rarely been developed, with the exception of a few cases limited to the analysis of the operational safety of complex hydraulic systems. However, it is possible to design, develop and improve the performance of such systems, which, open to their environment, integrate subsystems and elements, often complex, interactive and with multiple feedbacks, in terms of functionality.

The process of systems engineering is a logical sequence of interrelated activities, gradually transforming input elements into output products to achieve the mission or objective of the system (Jackson et al 2010).

Bouchrit Rouissat

b_rouissat@yahoo.fr

1 RISAM Laboratory, Faculty of Technology, University Abou-Bekr Belkaid Tlemcen, BP 119, 13000 Tlemcen, Algeria
We can distinguish, in systemic, four fundamental concepts, namely: the concept of interaction, the concept of totality, the concept of organization and the concept of complexity.

Two approaches are generally adopted for the identification and the analysis of systems: structural view based on a set of constituents (subsystems) in mutual interaction and interaction with the environment integrated according to the mission. Dynamic view based on a sequence of processes (activities, functions) in interaction with the environment chained (coordinates) according to the mission or the results (Grumbach and Thomas 2020).

The systems approach takes a chronological path including the design, feasibility, development, production, use and withdrawal phase of the system. Taking into account the increasing complexity of systems, it is imperative that stakeholders must be involved in the development of the system. This development integrate aspects related to the identification and analysis of needs as the purpose of the system, the involvement of actors and stakeholder satisfaction, technical performance and efficiency measures, analysis of operational requirements and maintenance and finally the implementation of the quality function of the system (Baron and Allegro 2019). 
The decision to implement a system is based on the functional service it brings to its deployment environment. Systems engineering is the basis of this decision reasoning (Ramosaj and Berisha 2014).

The systemic approach based on the functional aspect of systems, whether natural or artificial, is used either for the design of new systems to be implemented or for the analysis of the efficiency of existing systems. This paper, by adopting a systemic approach, aims to analyze the functionality and the performance of water resources system Boughrara on the technical and institutional level.

\section{Application of the approach to the water resources system}

The water resources system is a natural and artificial system, open to its environment, dynamic, complex and with feedbacks between its subsystems and elements. The development of relationships and links between technical systems (surface and underground mobilizations, water purification and treatment, protection of ecosystems, desalination and others), the definition of needs and requirements, long-term constraints for disrupting sustainable development and the degree of stakeholder involvement allow to solve, with relevance, all the problems linked to the integrated and participatory management of water resources (Dacko 2009).

In the management of water resources, the systemic concept adds to the concept of "water management" the notions of organization, interdependence, prioritization, coordination and integration (Dobner and Frede 2016).

Due to the large number of multi-sectoral consultations and decisions, variable, depending on the environment, systems engineering tends to search an optimal solution to the water resources system and to optimize planning and strategies in the sector (Datta and Harikrishna 2005).

The systemic approach intended to coordinate the integrated management of water resources for all sectors and interest groups and at different levels: scarcity, excess, floods, siltation, water quality, etc. (Oyebode and Igbi 2018).

The systems analysis, applied to water resources in general, and particularly Boughrara system aims to integrate water resource management in a development policy and a triple mastery of resources, ecosystems and uses. Based on this systemic approach and considering the functional analysis of the Boughrara system, located north-west of Algeria and composed of several water projects, this paper constitutes a multi-criteria study of the performance of the system by requirements correlations at the level of subsystems and its components.

\section{Conceptualization of the Boughrara system}

In system engineering, the main mission of the system Boughrara to be analyzed is to produce, quantitatively and qualitatively, water by surface mobilization through the Boughrara dam. These waters will be used for the supply of drinking water, irrigation and ecosystem preservation (Rouissat 2007).

It is composed of interactive subsystems, reflected, projected, conceived and realized in a singular way. The temporal assembly of these subsystems has given rise, in terms of functionality and performance, to a complex global system by the strong interactions of the subsystems below:

Subsystem 1 hydrology of the main and residual watershed affects the inputs of the river, and therefore the quota shares to be allocated to the water transfers planned downstream of the dam, the solid transport coming from watershed affects also the useful capacity of the reservoir and therefore the allocation volumes,

Subsystem 2 the exploitation of the reservoir of the dam is also a parameter to be considered since it may constitute a constraint as to the downstream use of the waters mobilized,

Subsystem 3 the mobilization dam is the core of the system, its response to the various internal and external stresses influences the reliability of the system,

Subsystem 4 the presence of a wastewater treatment plant just upstream of the reservoir, the purified water quality of which affects the overall performance of the system. The various discharges, particularly industrial ones, also have an impact on the quality of the water mobilized and therefore conditioning some criteria of the subsystem transfers downstream of the dam,

Subsystem 5 water transfers to the cities of Oran and Maghnia which are closely linked to the quantitative and qualitative aspect of the waters mobilized at the dam. Water released in the river downstream of the dam intended for the irrigation of agricultural lands of the middle and low Tafna is also conditioned by these two aspects of the water present in the dam reservoir (Rouissat 2016).

Performance evaluation is an essential element of systems steering. The operating safety is inseparable from this performance of the systems. This action aims at managing the requirements of the system during its life cycle. The importance is to highlight the criteria that could compromise the missions of the system and to validate its response to these planned objectives.

The main functions reflect the object of the action of a system. For the application to the system studied, the upstream reservoir and the downstream environment are connected through the structure of the system.

System performance should be analyzed according to the chronology of the process and according to the 
hierarchy of the participation of the subsystems and elements of the system in the achievement of its objectives. Figure 1 shows the chronology of the functional process steps of the system to be analyzed.

The exploration and functional identification of the system aims to analyze and manage its requirements during its life cycle, the production of parameters influencing its requirements, the roles of actors and stakeholders and the exploration of evaluation criteria. In a environment that depends increasingly on complex, critical, and intertwined systems, requirements engineering is crucial to developing and preserve safety-critical systems (Martins and Gorschek 2017). Figure 2 shows the schematic exploration of Boughrara system.

Figure 3 shows, in a system engineering approach, the conceptualization of the system in relation to its main mission which is the production of water for various customers.

\section{Typology of the relations between the uses of water resources in Boughrara system}

The different users of water have complementary or antagonistic interests and objectives: the support function and that of leisure and tourism are generally complementary while the function of supplying drinking water often clashes with the function of supplying industrial or agricultural water either in terms of quantity and quality. Likewise, the energy function often comes into conflict with that of leisure and tourism or natural environment (question of minimum flows). These antagonisms or conflicts of use are inevitable insofar as the water resource is a system in which all the elements are interconnected. These compatibilities and incompatibilities between the main uses are summarized in Table 1. This assessment of the various relationships (inspired by the work of E. Reynard 2000) of this kind makes it possible to establish the bases for the management of uses by taking care to define orders of priority between the different uses.

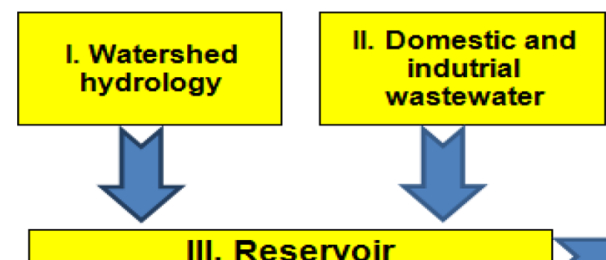

III. Reservoir

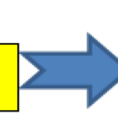

Fig.1 Functional chronology of the system Boughrara
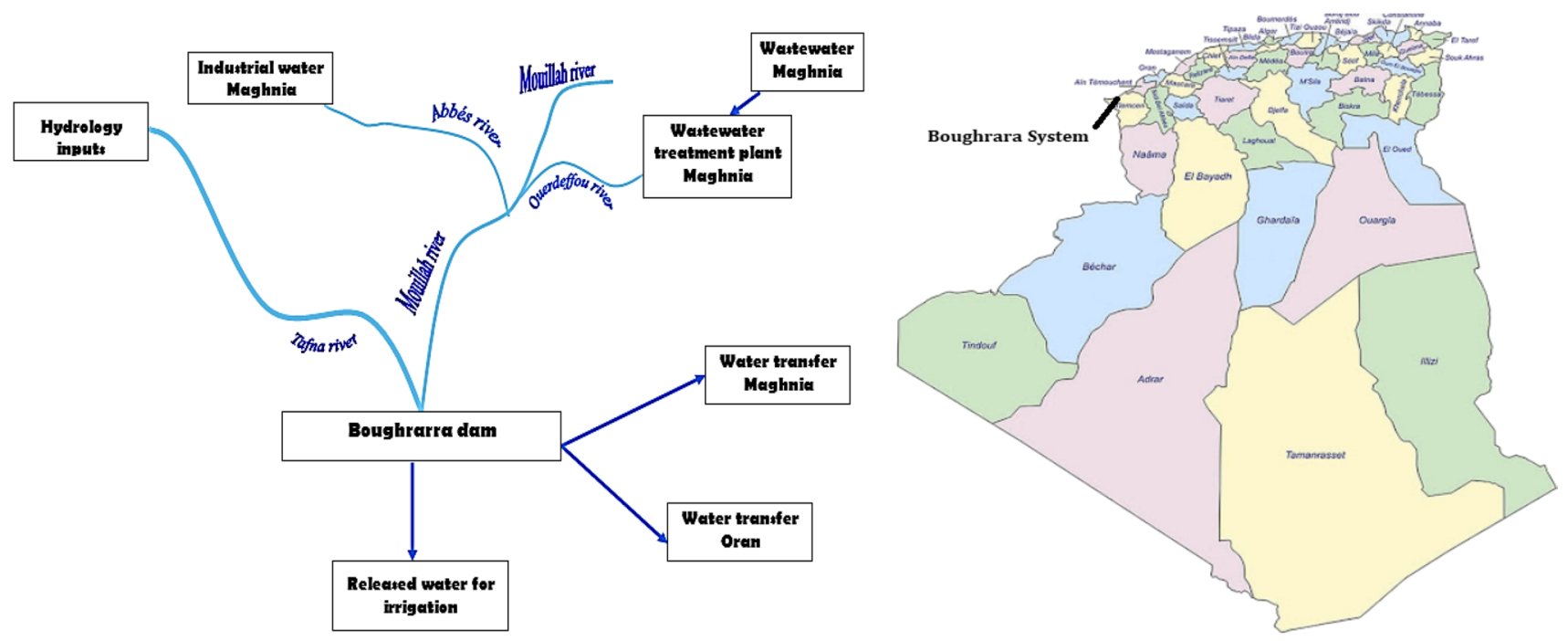

Fig. 2 Schematic exploration and identification of Boughrara system 


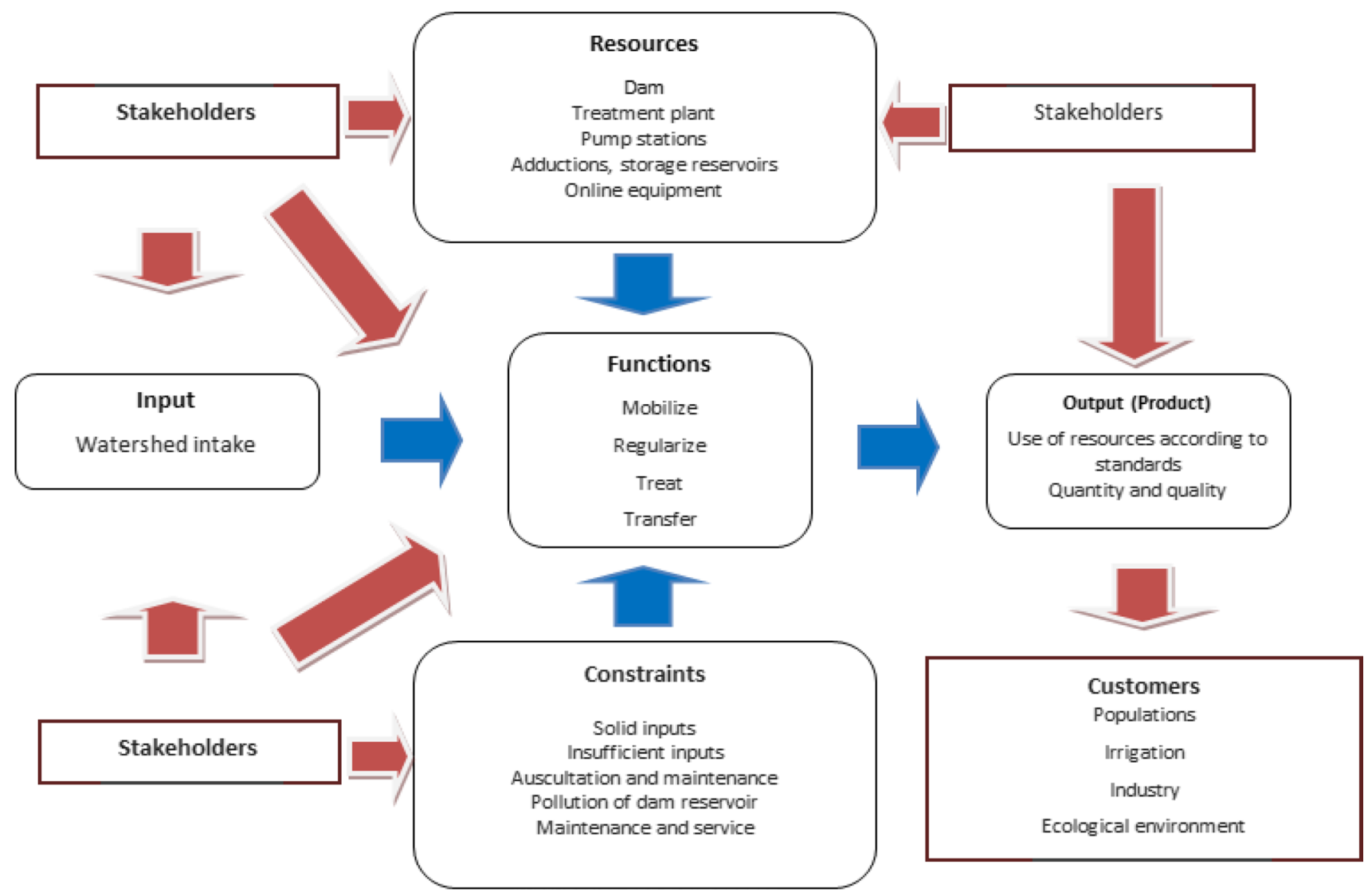

Fig. 3 Conceptualization of Boughrara system

Table 1 Compatibilities and incompatibilities of various types of resource use in Boughrara system

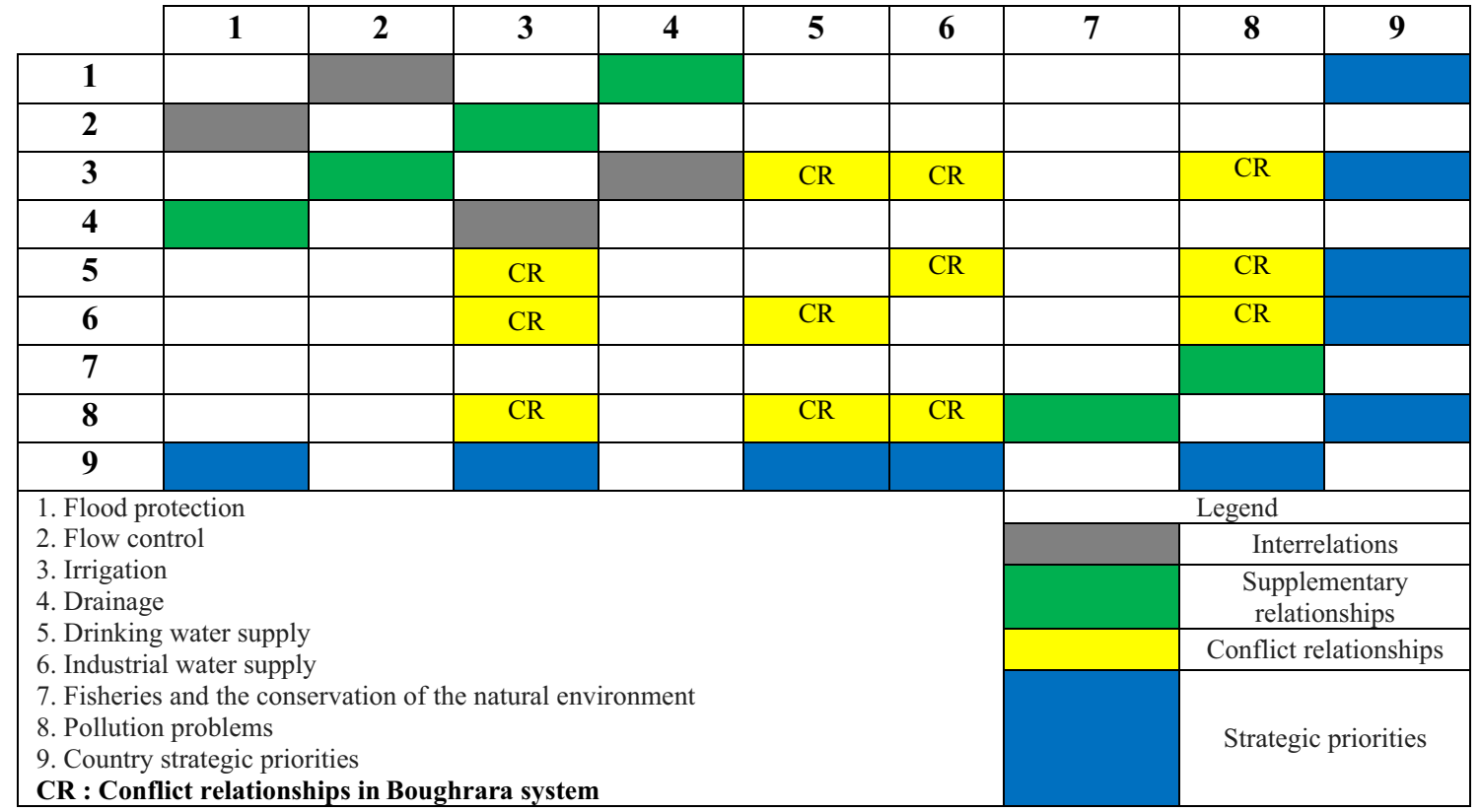


At the level of the Boughrara system, and in relation to the uses of the resource mobilized by the dam, four functions come into conflicting situations:

- In terms of satisfaction of needs (quantity of the resource): this concerns the drinking water supply function, the irrigation water supply function and the industrial water supply function.

- In terms of water quality: the function of protection against pollution is in conflict with the functions of drinking, industrial and irrigation supply and is influenced by the quality of domestic and industrial discharges upstream of the dam.

Table 1 summarizes these situations of compatibility and incompatibilities between the main uses of the resource.

\section{Functional analysis of the system}

The analysis methods allow the identification of the functions to be insured. They are based on a structured hierarchical, top-down and modular approach. From successive refinements, these methods which rely very often on a graphic formalism lead to specifications. Each level can then be decomposed by respecting the input-outputs of the higher level. The decomposition continues until the level of detail deemed sufficient for the analysis is reached. The structural aspect refers to the way the system is composed while the functional analysis deals with the purpose of the system.

For the Boughrara system, the resources constitute the inputs from the river to the dam. These waters, in terms of quality, are influenced by the discharges from the treatment plant of the town and industrial units.

The requirements of the system are the quantitative and qualitative satisfaction of the needs for irrigation, drinking water supply and industrial water with regular volumes. The water needs of the different sectors (drinking water, irrigation and industry) are integrated in conflict situations. Pollution of the dam reservoir by upstream discharges greatly influences the objectives of the system.

Also, the actors (different agencies) in charge of management have responsibilities at the level of the subsystems without having a vision of the overall system and its missions.

Functional analysis provides both a technical and a pedagogical method that is part of a rational approach and provides sufficient benchmarks for analyzing, selecting

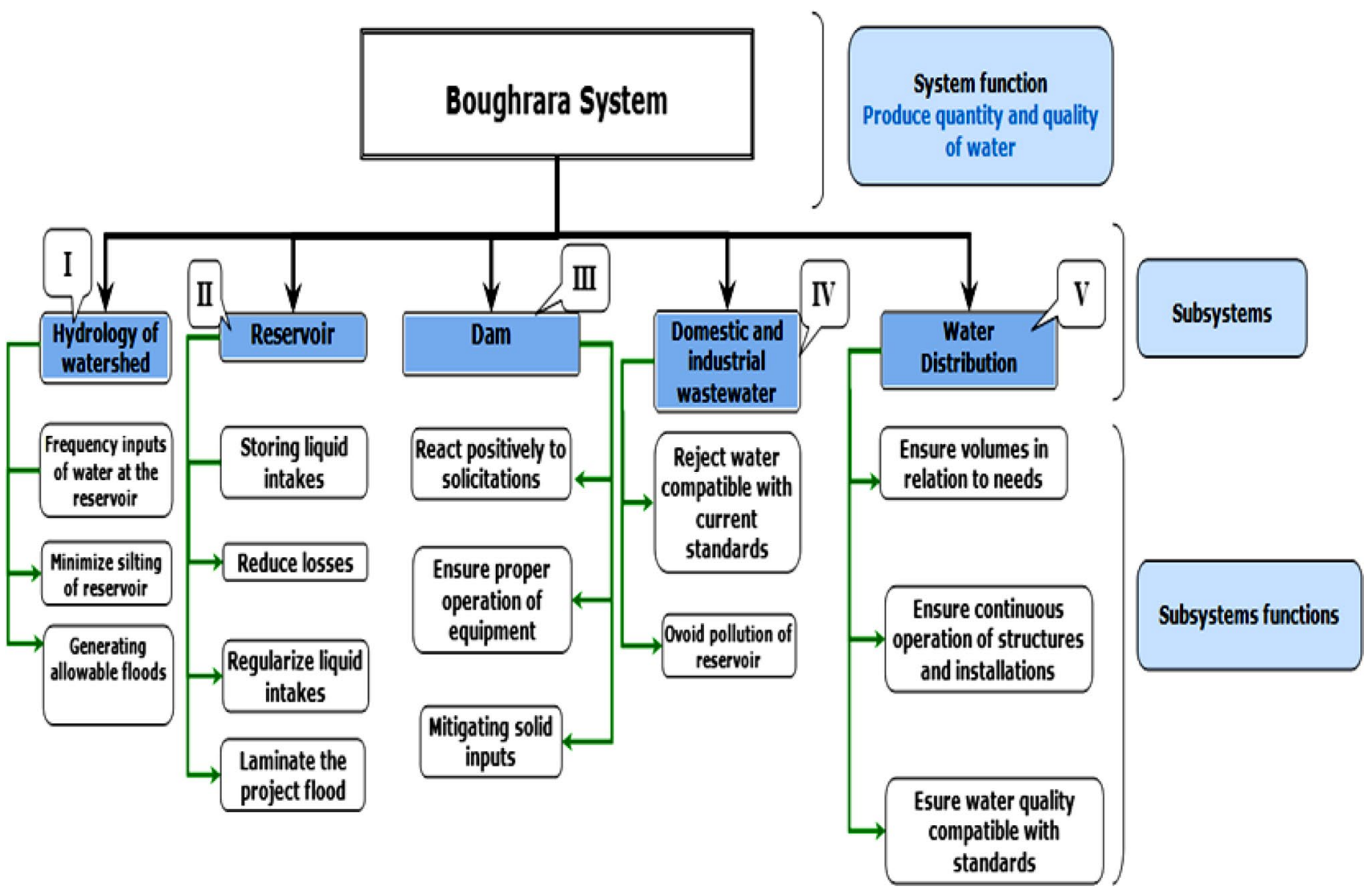

Fig.4 Functional decomposition of the System 
and using a system. The subsystems are analyzed by their functionality in a hierarchical diagram. The grouping of functions allows the analysis of allocations (Baron and Allegro 2019). Figure 4 illustrates the functional decomposition of the Boughrara system declined at the scale of the subsystems and the components.

Figure 5 illustrates the functional diagram of the Boughrara system declined at the scale of the components in relation to its main requirements. The results of the functional analysis of the performance of water resources systems offer better results than that based on the physical architecture of the system since it involves the missions of each element in order to achieve the objectives of the global system.

In a functional chronological approach, functional analysis of the system takes into account:

- quantitative and qualitative water inputs to the dam (system inputs).

- the mobilization, regularization, treatment function at the dam level which represents the process of the system

- the water transfer function for drinking, industrial and agricultural water supply.

- the function of protecting ecosystems through the minimum flows to be ensured downstream.
In a system engineering approach, the process (water production) requires resources (the dam, the treatment station, the pumping stations, the supply pipes and the necessary equipment) and records constraints (the transport solid at the dam, inadequate inputs, safety of the dam related to its behavior, possible pollution of the dam reservoir and failure of maintenance). The requirements of the system can be summed up in the satisfaction of water needs in terms of quantity and quality.

Depending on the inputs, resources, constraints and technical requirements of the system, it is imperative to integrate the actors (managers) and stakeholders (users of the system's product) in its process which constitute the institutional aspect of management of the system.

\section{Hierarchy of Boughrara system requirements}

A system must, by its organization, obey to: respond to the needs, expectations and constraints of all stakeholders, be acceptable to and for the environment (physical, social, ecological ...), and represent a globally balanced and optimized solution throughout its life cycle (AFIS 2005). The identification of the influence parameters on the requirements of the Boughrara system must take into account the hydrological

\section{SYSTEME REQUIREMENTS}

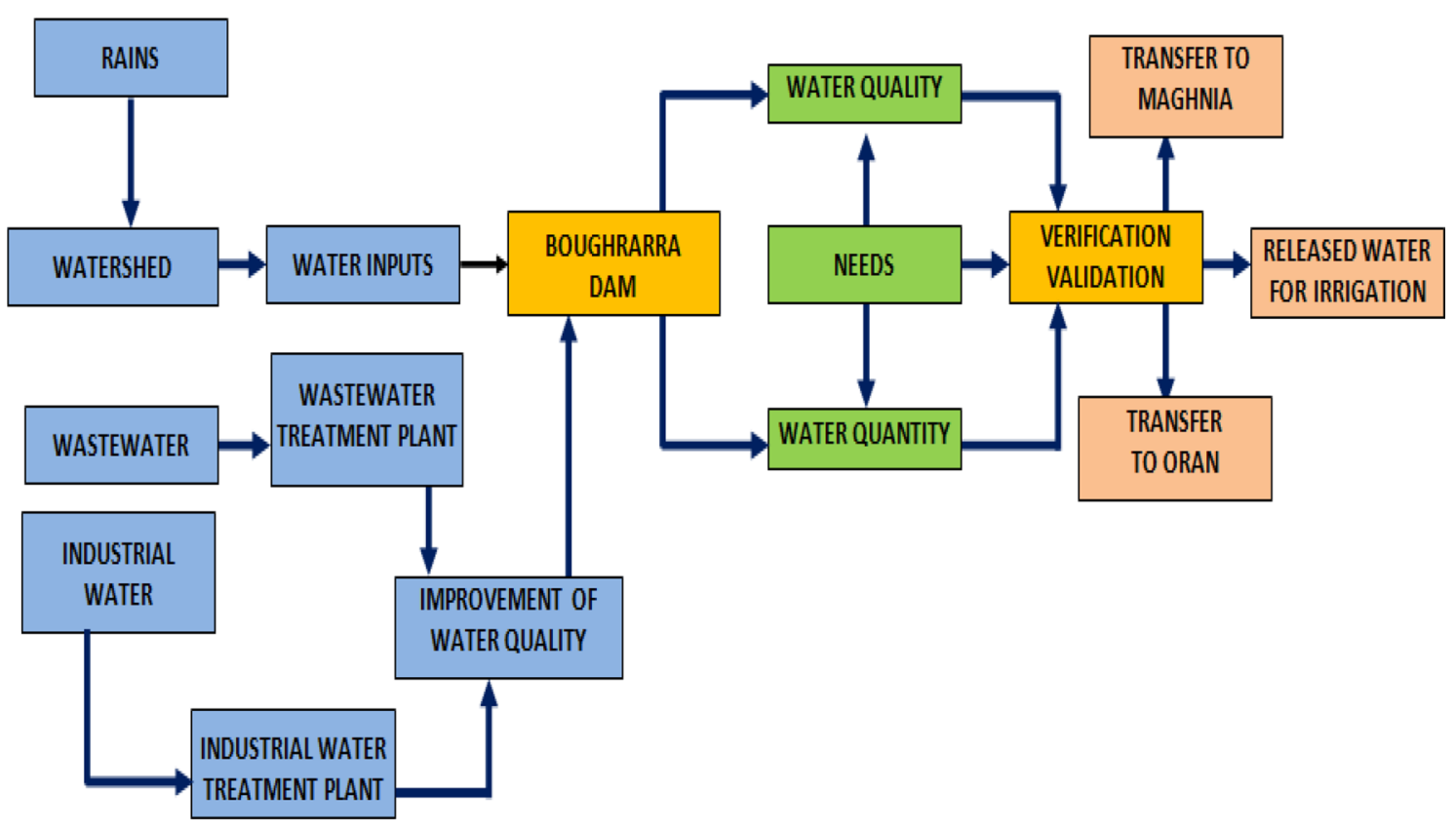

Fig. 5 Functional diagram of the System in relation to its requirements 
functions, the technical criteria, flows of water but also the evolution of the water demand (Rouissat 2009).

In addition to the natural parameters, it is necessary to add the anthropic factors and the means of actions of the actors. This refers to the socioeconomic, cultural, institutional, political, regulatory, scientific and technical context (Benblidia 2011).

Figure 6 shows the hierarchy of requirements of the Boughrara system against the supports of stakeholder needs.

\section{System management, definition and roles of stakeholders}

Watershed management requires good stakeholder knowledge: those involved in decision-making in watershedscale water and soil management, and those who will be affected by decisions. Once the context has been analyzed, it is possible to seek to involve in the watershed management the good combination of water actors at the appropriate levels. In order to identify stakeholders involved in watershed management and those affected by decisionmaking, it is useful to establish stakeholder support, roles and responsibilities.

Taking both approaches into account, the evaluation of water systems raises two following questions: Who takes part in decision making about the implementation and management of water system? Are all shareholders involved and do they have an equal share in the decision-making progress? (Dobner and Frede 2016).

Figure 7 summarizes stakeholder involvement in the functions of the water resources system at the Boughrara watershed scale.

\section{Constraints and challenges of the system}

Factors such as growth and demographic change, economic development and climate change clearly have a major impact on water resources. Similarly, water

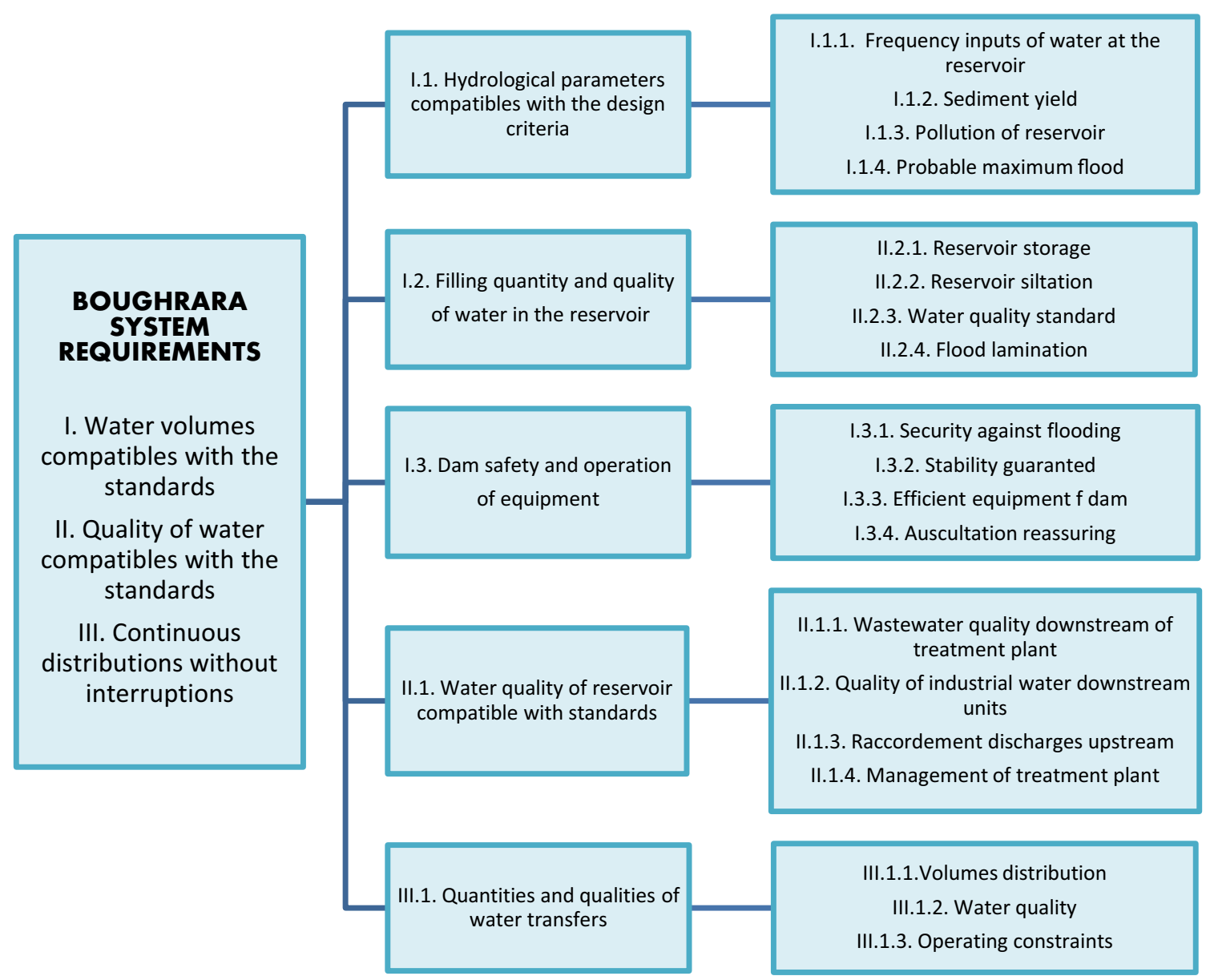

Fig. 6 Hierarchy of Boughrara system requirements 
resources have a significant impact on production and economic growth, on health and livelihoods, and on national security. The search for a balance between economic development and preservation of water resources subjects the watershed manager to enormous pressures, risks and conflicts. It is not only water security which influences the achievement in economic growth and human development, but also the level of use of water in different sectors, condition of the water environment and technological and institutional capacities in water sector (Mukherjee 2016).

Table 2 summarizes, for the different functions, the constraints to which the system Boughrara is submitted.

Table 2 Constraints and challenges of the system

\begin{tabular}{|c|c|c|c|}
\hline Administrative & $\begin{array}{l}\text { Coordination } \\
\text { of services } \\
\text { water managers }\end{array}$ & $\begin{array}{l}\text { Coordina- } \\
\text { tion with the } \\
\text { services of } \\
\text { regional plan- } \\
\text { ning }\end{array}$ & $\begin{array}{l}\text { Information to } \\
\text { the user public }\end{array}$ \\
\hline Economic & $\begin{array}{r}\text { Offer and } \\
\text { demand }\end{array}$ & Pricing & $\begin{array}{l}\text { Users categories } \\
\text { and possible } \\
\text { conflicts }\end{array}$ \\
\hline Cultural & Traditions & $\begin{array}{l}\text { Symbolic } \\
\text { charge }\end{array}$ & $\begin{array}{l}\text { Irrational behav- } \\
\text { ior }\end{array}$ \\
\hline Scientific & $\begin{array}{l}\text { Reliability and } \\
\text { frequency of } \\
\text { measurement } \\
\text { on the control } \\
\text { network }\end{array}$ & $\begin{array}{l}\text { State of } \\
\text { research }\end{array}$ & Global analysis \\
\hline Natural & $\begin{array}{l}\text { Resources } \\
\text { available }\end{array}$ & $\begin{array}{l}\text { Hydrology and } \\
\text { hydrogeol- } \\
\text { ogy }\end{array}$ & $\begin{array}{l}\text { Natural charac- } \\
\text { teristics }\end{array}$ \\
\hline \multicolumn{4}{|l|}{$\begin{array}{l}\text { Climatic } \\
\text { changes }\end{array}$} \\
\hline Social & Demography & $\begin{array}{l}\text { Agricultural } \\
\text { development }\end{array}$ & $\begin{array}{l}\text { Industrial devel- } \\
\text { opment }\end{array}$ \\
\hline Environmental & Pollution & Erosion & Flow control \\
\hline
\end{tabular}

\section{Production of evaluation criteria}

Water resource management goals in a watershed in relation to sustainable management has as objectives: protecting the quantity of resources, protecting the quality of resources, preserving the health of ecosystems, ensuring socioeconomic well-being and applying the principles of good governance (UFM 2013).

Table 3 shows water resources management goals and their associated indicators which can be applied to the Boughrara system.

Table 3 Goals of water resources governance

\begin{tabular}{ll}
\hline Goals & Indicators \\
\hline $\begin{array}{l}\text { Protection against exhaustion } \\
\text { Quantity) }\end{array}$ & Quantity of water available \\
& Water consumed \\
& Quantitative problems \\
Protection against excess & Floods probability \\
Pollution control & Quality problems \\
& Vulnerability \\
& Contaminated areas \\
Preservation of ecosystems & Contribution to base flow of water \\
(Sustainability) & levels \\
Socioeconomic well-being & Dependence on drinking water \\
& Dependence on agricultural water \\
& Dependence on industrial water \\
& Efficiency-Use of resources \\
& Conflicts of use \\
Application of governance & User Awareness \\
principles & Resource strategy and programs \\
\hline
\end{tabular}

\section{Evaluation grid of the system}

In order to evaluate the performance of Boughrara system, and in addition to the production of the indicators, some criteria must be defined that allow assessment in terms of scoring by assigning ratings relating to the qualitative aspect of the indicators. Table 4 summarizes the scoring grid of the indicators for the evaluation of the system. 


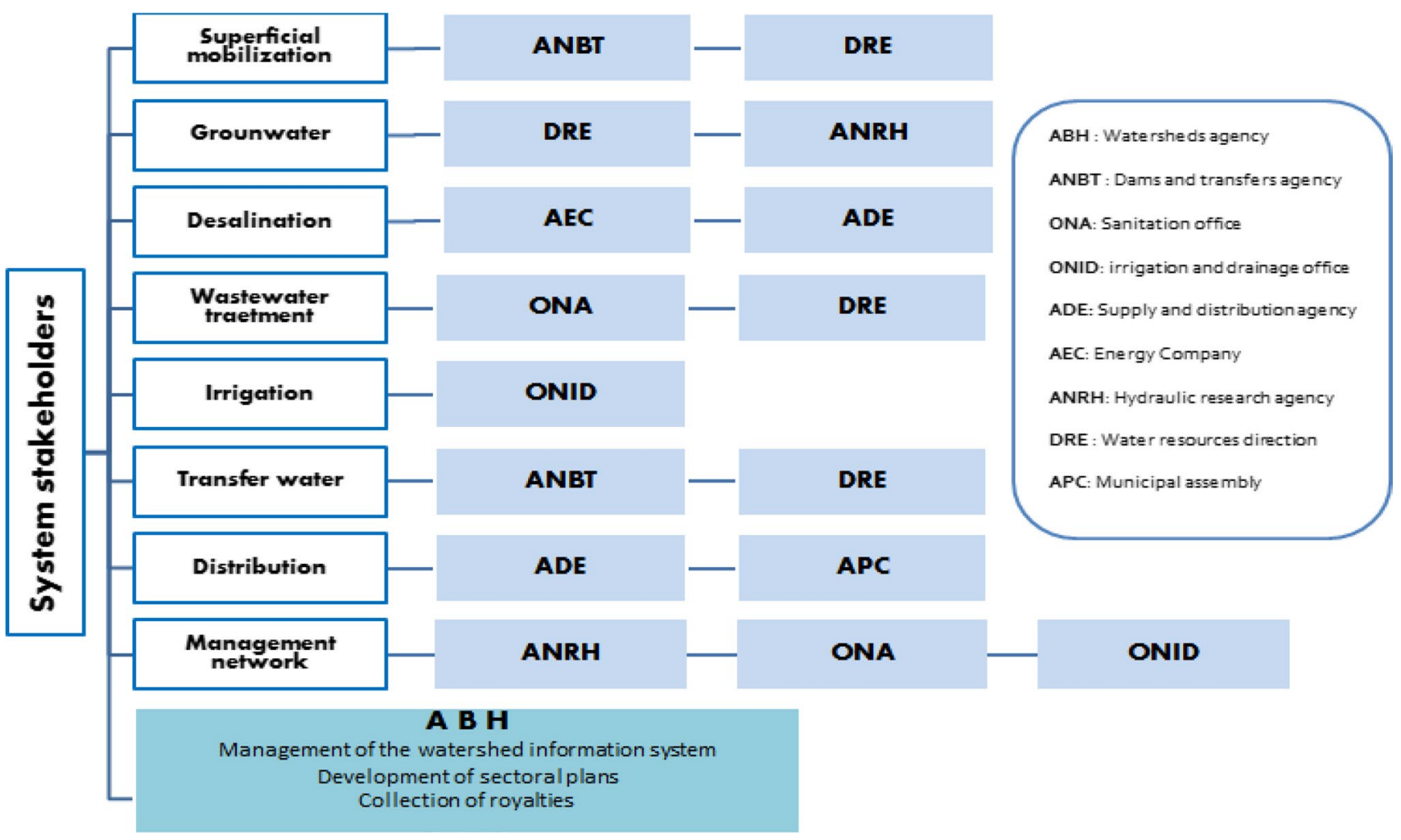

Fig. 7 Roles of stakeholders on Boughrara system functions

Table 4 Rating grid for system evaluation indicators

\begin{tabular}{lll}
\hline Indicator response & Rating grid & Symbol \\
\hline Relevance & $\begin{array}{l}\text { Significant, closely linked to } \\
\text { objectives } \\
\text { Sensitive to Change }\end{array}$ & A \\
& Useful for stakeholders & C \\
Based on available and / or & D \\
easily accessible data & \\
Efficiency & E \\
Quality of use & easy to interpret & F \\
\hline
\end{tabular}

The evaluation of the system taking into account the production of the indicators, their evaluation and the grading scale requires thorough surveys among the various stakeholders. For this research, the evaluation of the system was done at the scale of the groups of indicators and through survey of management actors which represent the various agencies in charge of mobilizing, purifying and transferring water.

Table 5 illustrates a qualitative summary grid of the Boughrara system at the indicator group level.
Table 5 Scoring grid of system evaluation indicators

\begin{tabular}{lcccccc}
\hline Groups of indicators & A & B & C & D & E & F \\
\hline Availability of water resources & $*$ & $*$ & $*$ & & & $*$ \\
Uses and allocation & $*$ & $*$ & $*$ & & & \\
$\quad$ Management of water demand & $*$ & & $*$ & & $*$ & \\
$\quad$ Water Quality control (Pollution) & $*$ & & $*$ & $*$ & & $*$ \\
$\quad$ Evaluation and management of informa- & $*$ & $*$ & $*$ & $*$ & $*$ & $*$ \\
$\quad$ tion & & & & & & \\
$\quad$ Level of water resources governance & $*$ & $*$ & $*$ & $*$ & & \\
\hline
\end{tabular}

\section{Improved system performance}

In the case of the Boughrara system, it is the water supply of the various sectors which constitutes the operational element, that is to say the element which realizes the distribution of waters in order to satisfy the needs. Enablingproducts are the means necessary to carry out the operational function of the system but do not participate directly in this function. 
To improve system performance, the challenge is to adopt an integrated approach to water resources management by creating an authority to administer the entire river basin and implement a more participatory strategy integrating both uses, users and stakeholders with the different feedback loops. Development of supportable water management strategies includes identification of vulnerability and adaptation possibilities, followed by an effect analysis of these adaptation strategies under different possible futures (Oyebode and Igbi 2018).

Table 6 illustrates the institutional improvements for the integrated management of water resources in Boughrara system.

Table 6 Institutional improvements for the integrated management water resources in Boughrara system

\begin{tabular}{|c|c|c|c|}
\hline Subsystems & $\begin{array}{l}\text { Current actor } \\
\text { of manage- } \\
\text { ment }\end{array}$ & $\begin{array}{l}\text { The need for } \\
\text { participatory } \\
\text { coordination } \\
\text { with }\end{array}$ & $\begin{array}{l}\text { Impact on perfor- } \\
\text { mance }\end{array}$ \\
\hline \multirow[t]{3}{*}{ Hydrology } & ANBT & ONA & $\begin{array}{l}\text { Protection of the } \\
\text { water environ- } \\
\text { ment } \\
\text { Operation of } \\
\text { sanitation } \\
\text { infrastructure } \\
\text { Fighting all } \\
\text { sources of } \\
\text { water pollution }\end{array}$ \\
\hline & & $\mathrm{ABH}$ & $\begin{array}{l}\text { Managing the } \\
\text { information } \\
\text { system at the } \\
\text { watershed scale }\end{array}$ \\
\hline & & ANRH & $\begin{array}{l}\text { Study of } \\
\text { hydrological } \\
\text { phenomena } \\
\text { Establish and } \\
\text { manage a flood } \\
\text { forecasting } \\
\text { network }\end{array}$ \\
\hline $\begin{array}{l}\text { Exploitation of } \\
\text { the reservoir }\end{array}$ & ANBT & ONA & $\begin{array}{l}\text { Protection of the } \\
\text { water environ- } \\
\text { ment } \\
\text { Operation of } \\
\text { sanitation } \\
\text { infrastructure } \\
\text { Fighting all } \\
\text { sources of } \\
\text { water pollution }\end{array}$ \\
\hline
\end{tabular}

\begin{tabular}{|c|c|c|c|}
\hline Subsystems & $\begin{array}{l}\text { Current actor } \\
\text { of manage- } \\
\text { ment }\end{array}$ & $\begin{array}{l}\text { The need for } \\
\text { participatory } \\
\text { coordination } \\
\text { with }\end{array}$ & $\begin{array}{l}\text { Impact on perfor- } \\
\text { mance }\end{array}$ \\
\hline & & $\overline{\mathrm{ABH}}$ & $\begin{array}{l}\text { Managing the } \\
\text { information } \\
\text { system at the } \\
\text { watershed scale } \\
\text { Collect royalties } \\
\text { imposed by } \\
\text { legislation }\end{array}$ \\
\hline $\begin{array}{l}\text { Mobilization } \\
\text { dam }\end{array}$ & ANBT & ANRH & $\begin{array}{l}\text { Establish and } \\
\text { manage a flood } \\
\text { forecasting } \\
\text { network }\end{array}$ \\
\hline \multirow[t]{3}{*}{$\begin{array}{l}\text { Wastewater } \\
\text { treatment } \\
\text { plant }\end{array}$} & ONA & ONID & $\begin{array}{l}\text { Management of } \\
\text { the operation } \\
\text { and mainte- } \\
\text { nance of equip- } \\
\text { ment and } \\
\text { Hydraulic infra- } \\
\text { structure in } \\
\text { irrigation areas }\end{array}$ \\
\hline & & DRE & $\begin{array}{l}\text { Raccordement } \\
\text { discharges } \\
\text { upstream }\end{array}$ \\
\hline & & APC & $\begin{array}{l}\text { Raccordement } \\
\text { discharges } \\
\text { upstream }\end{array}$ \\
\hline \multirow[t]{3}{*}{ Water transfers } & $\mathrm{ADE}$ & ANBT & $\begin{array}{l}\text { Water quantity } \\
\text { in the dam } \\
\text { reservoir }\end{array}$ \\
\hline & & ONA & $\begin{array}{l}\text { Water quality } \\
\text { in the dam } \\
\text { reservoir }\end{array}$ \\
\hline & & ANRH & $\begin{array}{l}\text { Establish and } \\
\text { manage a flood } \\
\text { forecasting } \\
\text { network }\end{array}$ \\
\hline
\end{tabular}

\section{Conclusion}

The prospective framework for the integrated management of the Boughrara system resulted in the identification of indicators for evaluating the performance of the system linked to compliance with its requirements and their parameters of influence on quantitative, qualitative and sustainable preservation of water. The analysis applied to Boughrara system has revealed interesting results based on a global approach to problems and constraints related to the performance of complex systems. The contribution of the functional analysis led to the definition of the needs 
and requirements of the system, in terms of functions and independently of physical choices. The analysis also made it possible to highlight, in a lucid way, the effect of the institutional framework on the functioning and the performance of the system studied and the involvement of all the stakeholders according to the objectives of the system and not in relation to the sectors of activity.

Finally, and based on the analysis of the requirements, the system evaluation indicators were selected and produced by group typology (quantitative availability, uses, resource management, quality and level of governance).

These indicators constitute the dashboard for the governance of water resources at the watershed level and allow the monitoring of system evaluation at the temporal level and the one relating to changes in its environment in order to adapt the process to these changes and ensure the requirements of the various customers of the system and the satisfaction of the stakeholders.

Acknowledgements The authors wish to thank the staff of the agencies and offices of water resources sectors for their cooperation.

Funding The author(s) received no specific funding for this work.

\section{Compliance with ethical standards}

Conflict of interest The authors declare that there is no conflict of interest regarding the publication of this article.

Ethical approval This article does not contain any studies with human participants or animals performed by any of the authors.

Open Access This article is licensed under a Creative Commons Attribution 4.0 International License, which permits use, sharing, adaptation, distribution and reproduction in any medium or format, as long as you give appropriate credit to the original author(s) and the source, provide a link to the Creative Commons licence, and indicate if changes were made. The images or other third party material in this article are included in the article's Creative Commons licence, unless indicated otherwise in a credit line to the material. If material is not included in the article's Creative Commons licence and your intended use is not permitted by statutory regulation or exceeds the permitted use, you will need to obtain permission directly from the copyright holder. To view a copy of this licence, visit http://creativecommons.org/licenses/by/4.0/.
Baron C, Allegro BD (2019) About adopting a systemic approach to design connected embedded systems: a MOOC promoting systems thinking and systems engineering. J Syst Eng Wiley Period 23:261-280. https://doi.org/10.1002/sys.21513

Benblidia M (2011) Water efficiency and economic approach. National Study, Final Version

Berim R, Gentrit B (2014) Systems theory and systems approach to leadership. ILIRIA Int Rev 1(1):59-76. https://doi.org/10.21113 liir.v4i1.53

Dacko M, Dacko A (2009) Management of the natural environment. Polish J Environ Stud 18(2):145-150

Datta B, Harikrishna V (2005) Optimization applications in water resources systems engineering. Div Am Soc Civ Eng Res J IIT Kanpur, pp 57-64

Dobner P, Frede HG (2016) water governance: a systemic approach. J Soc Water Technol 6:79-87. https://doi.org/10.1007/978-3-31918971-0_6

Grumbach JL, Thomas LD (2020) Integration principles for complex systems. J Syst Eng, INCOSE, pp 1-23

Jackson S, Hitchins D, Eiser H (2010) What is systems approach. J Insight INCOSE 13(1):41-43. https://doi.org/10.1002/inst.20101 $3141 \mathrm{a}$

Martins LEG, Gorschk T (2017) Requirements engineering for safety-critical systems. J IEEE Softw 34(4):49-57. https://doi. org/10.1109/MS.2017.94

Mukherjee S (2016) Role of water resources management in Economic development. J Yojana 8(196):7-11

Oyebode OJ, Igbi AE (2018) Design of water distribution system for sustainable water management. J Water Resour Eng Manage 5(2):37-44

Reynard E (2000) Gestion patrimoniale et intégrée des ressources en eau dans les stations touristiques de montagne. Travaux et Recherches $\mathrm{n}^{\circ} 17$. Université de Lausanne, Institut de Géographie, pp 43-46

Rouissat B (2007) System analysis applied to water projects World water day. University of Tlemcen, Algeria

Rouissat B (2016) Doctoral thesis: systemic analysis applied to hydraulic developments. University of Tlemcen, Algeria

Rouissat B, Bekkouche A, Smail N (2009) Water resources management in Algeria, situation, challenges and contribution of the systems analysis. In: International symposium (AUF), Crossed eyes for the millennium development goals, Tlemcen, Algeria.

UFM: Union For the Mediterranean (2013) Blue Plan. In: Proceedings of the Technical Workshop on Indicators for Integrated Water Resources Management. Barcelone

Publisher's Note Springer Nature remains neutral with regard to jurisdictional claims in published maps and institutional affiliations.

\section{References}

Afis (2005) Process engineering system, standardized processes. Working Group: Methods and Tools 